\title{
A questão da correlação entre a análise automática das finalizações prosódicas e a separação intuitiva de frases em textos longos ${ }^{10}$
}

Renata Rosa; Fernanda Consoni; Waldemar Ferreira Netto

\section{Objetivos}

Este projeto tem por objetivo verificar a correlação entre a segmentação automática da fala realizada pela rotina ExProsodia elaborada por Ferreira Netto (2006) e dados de percepção de fala. A percepção dos procedimentos de segmentação frasal, com propósito de finalização, pressupõe que tanto o falante quanto o ouvinte tenham estabelecido um valor ou um procedimento fixo que caracterize a finalização da frase e que o reconheçam durante sua execução. Através de teste de percepção é nosso objetivo verificar se há uma correlação entre o que os ouvintes consideram como final de frase em textos longos e os dados de segmentação de frase propostos pela rotina Exprosodia.

\section{Metodologia}

Elaboramos um teste piloto no qual era apresentado um trecho de fala espontânea para que os ouvintes sinalizassem, na transcrição, quais pontos eles reconheciam como final de frase. $\mathrm{Na}$ transcrição apresentada aos sujeitos participantes do teste,

\footnotetext{
${ }^{10}$ CONGRESSO NACIONAL DE FONÉTICA E FONOLOGIA, 10 / CONGRESSO INTERNACIONAL DE FONÉTICA E FONOLOGIA, 4. Niterói, 2008.
} 
foram eliminadas repetições, palavras truncadas e marcações de pausa, hesitação ou alongamento. Os textos transcritos foram apresentados em papel, com letras maiúsculas sem qualquer sinal de pontuação. O teste piloto foi aplicado em 12 sujeitos de ambos os sexos, com idade entre 20 e 35 anos, todos com escolaridade em nível superior. O piloto contou com duas etapas, na primeira, os sujeitos deveriam ouvir apenas uma vez a entrevista e pontuar onde eles julgavam ser os finais de frases. Na segunda etapa, os sujeitos podiam dispensar quanto tempo achassem necessário para fazer o teste e então fazer as marcações.

\section{Resultados Parciais}

Neste trabalho apresentaremos os resultados da segunda etapa. Os sujeitos fizeram marcas de finalização em 21 pontos da transcrição. Em apenas 6 pontos, houve unanimidade. A análise da gravação foi realizada pela rotina de análise prosódica automática desenvolvida no contexto do projeto Análise Automática da Entoação na Fala de Língua Portuguesa. Com base nos dados apresentados pela rotina, estabelecemos duas variáveis: tom grave em sílaba tônica final e tom grave em sílaba final. A comparação foi feita entre essas variáveis e a quantidade de marcas feitas pelos sujeitos em cada posição. A análise de correlação de Pearson apresentou um r2 de 0,84 para a variável tom grave em sílaba tônica final e 0,79 para a variável tom grave em sílaba final, em ambos os casos isso representa uma correlação entre média e forte. 


\section{Conclusões Parciais}

Esses resultados apontam para o fato de que tonicidade da sílaba final com tom baixo é um fator importante para o reconhecimento da finalização das frases. Apontam também para o fato de que com a análise automática da prosódia, tal como a desenvolvemos, há uma margem de erro reduzida para a segmentação de frases de fala espontânea. 